\title{
THE EFFECTIVENESS OF RUSSIAN ORGANIZATIONS: THE ROLE OF KNOWLEDGE MANAGEMENT AND CHANGE READINESS
}

\author{
Yu. A. ZELENKOV \\ Faculty of Business and Management, National Research University \\ Higher School of Economics, Moscow, Russia
}

\begin{abstract}
Many researchers believe that knowledge is the most important resource in the contemporary economy, but empirical studies show that knowledge management is not among the most used managerial tools. This gap can be explained with the hypothesis that knowledge management produces the significant impact on the effectiveness of organization only with the accompanying development of change management. Herewith the critical element of change management is a change readiness that allows to assess the possibility and feasibility of changes, consolidate and focus efforts, assess the adequacy of resources. This hypothesis is empirically tested using the partial least squares structural equation modeling (PLS-SEM) method on data for 103 Russian organizations. The results show that the empirical sample includes two statistically different datasets. The separating variable is the type of owner, so separate models were built for state-owned and private-owned organizations. For privateowned organizations, the hypothesis that knowledge management and changes readiness jointly affect effectiveness is fully confirmed. For state-owned organizations, knowledge management is not a factor of effectiveness. These results have two practical implications. First, managers who rely on the organizational knowledge should focus on the joint and coordinated implementation of knowledge management and change management. Special attention should be paid to the organizational context that supports individual change readiness. Second, state-owned organizations in Russia are less effective rather private ones, it is due to the fact that knowledge management for them is not the factor of effectiveness, that is in its turn a consequence of suppression of initiatives at the individual level.
\end{abstract}

Keywords: knowledge management, change management, change readiness, effectiveness of organization, private-owned organizations, state-owned organizations.

JEL: D20, D83, M14, O32.

Postal Address: National Research University Higher School of Economics, Moscow, Russia 20 Myasnitskaya ul., Moscow, 101000, Russian Federation

(c) Yu.A. Zelenkov, 2018

https://doi.org/10.21638/spbu18.2018.403 
Many researchers and management practitioners believe that intangible assets are the most significant resources in the contemporary economy. Companies that rely on traditional factors, namely, capital, cheap labor and natural resources, are forced out to the economic periphery. The most important of the intangible assets is the knowledge of the organization that determines its ability to adapt to constantly changing external conditions [Heisig, 2009].

Since the 1980 s, two relatively independent lines of research on the role of knowledge in economics have emerged in management science: the first is connected with the study of such a phenomenon as the intellectual capital (IC) of the organization, the second focuses on processes of knowledge management (KM). Research related to the IC mainly focuses on managing intellectual assets in a strategic perspective [Wiig, 1997]. KM as a management discipline has a more operational focus, it focuses on the processes associated with the creation, acquisition, and sharing of knowledge [Wiig, 1997].

However, research on management practices [Rigby, 2001; 2015] shows that KM is not among the most frequently used managerial tools, moreover, many managers have difficulty in determining how it can be adapted and incorporated into their activity [Inkinen, 2016].

Many authors (e.g. [Choo, 2006]) note that knowledge management is related to various aspects of change management (CM), so it can be assumed that only the joint implementation of KM and CM has a significant effect in the effectiveness of the organization [Zelenkov, 2016]. From this point of view the change readiness [Armenakis, Harris, 2009], which is formed on the basis of communications, broad awareness and the active involvement of employees, has a great importance.

The goal of this study is to quantify the joint impact of knowledge management and change readiness (CR) on the effectiveness of the organization. This paper is a revised and extended version of work [Zelenkov, 2018] presented at a Knowledge Management in Organization' 2018 Conference where the difference between KM practices in Russian state-owned and private-owned organizations was identified. In the previous paper regression model was used to assess the joint impact of KM and CR on effectiveness. In this study, we use partial least squares structural equation modeling (PLS-SEM) method that helps to analyze the relations between components of KM and CR (namely, organizational and individual support) and shed light to deep differences between roles of these components in state-owned and private-owned organizations. Secondly, this study is based on the extended data sample that includes data on 103 Russian organizations.

New results confirmed there are two groups of organizations that are very different in their KM practices. Organizations owned by private investors pay more attention to knowledge management and demonstrate greater effectiveness. For these organizations, the hypothesis of the study is fully confirmed. In organizations that belong to the state, knowledge management is not an essential factor. Probably, this could be explained by the fact that state-owned organizations still practice the Soviet management style, which relies on a hierarchy of decision-making and suppression of the employees' initiative, this complicates the search, sharing and use of knowledge. In general, such organizations are much less effective, this is the consequence of poor knowledge management practices.

\section{Related literature review}

\subsection{Theoretical model of knowledge management}

In the academic literature, the generally accepted definition of knowledge has not been formed until now. In the definition of this term, the hierarchy "data-informationknowledge" that was introduced by [Ackoff, 1989] is usually used. Later, in [Davenport,

RMJ 16 (4): 513-536 (2018) 
Prusak, 1998] the authors defined the data as objective facts about some events. In the context of an organization, data is usually stored as structured records of various transactions [Davenport, Prusak, 1998]. The individual can interpret the data in accordance with his goals, in this process of making the meaning, data is transformed into information, which, therefore, is even more subjective. Information is always processed in a certain context and influences the behavior or decisions of the individual. So, value of information depends on the degree of reduction of the uncertainty. Due to the limited rationality of the individual, information is always incomplete. In the organization, information is distributed through various networks, which can have both a technical (for example, e-mail) and purely social (informal communication) nature, and their various combinations are also possible [Davenport, Prusak, 1998].

By the definition of [Davenport, Prusak, 1998], knowledge is a mixture of accumulated experience, values, contextual information and expert knowledge that allows to evaluate and assimilate new experiences and new information. Knowledge is completely subjective since its carrier is an individual. Knowledge can also exist at the level of the organization, not only in the form of documents but also in the form of routines, norms, and procedures, as well as social relations.

Knowledge allows to transform data into information: assess its relevance in the specific context, highlight key components, remove obvious errors, create a more compact representation [Davenport, Prusak, 1998], also as make decisions, recognize and identify events, analyze the situation and adapt to it, plan and monitor the actions. Knowledge, unlike information, presupposes the presence of opinions and beliefs and implies action [Nonaka, Takeuchi, 1995].

In the literature, a generally accepted understanding of $\mathrm{KM}$ is not yet formed. [Heisig, 2009], who compared 160 models of knowledge management, notes that in addition to using different terminology, various authors distinguish, for example, from 2 to 9 processes. According to the [Heisig, 2009] survey, the authors of different models pay the greatest attention to the following processes (in parentheses the share of models that include the corresponding process is indicated): sharing (82\%), creation ( $74 \%)$, usage $(65 \%)$, storage $(52 \%)$, identification $(51 \%)$, and acquisition $(37 \%)$.

To start the discussion of the knowledge management we need to define management in general as a specific human activity. The subject of management is a person or a group creating administrative influences. The object of management is all that these managerial influences are oriented on. The work of the manager includes setting goals, organizing, motivating, evaluating and developing people [Drucker, Maciariello, 2008], this is more practice than science. Therefore, building an adequate conceptual model is very important from the point of view of creating an effective knowledge management system in practice.

The governance functions (goals setting, organizing, motivating, evaluating and developing people) identified by [Drucker, Maciariello, 2008] can be mapped to knowledge management processes.

The goal setting function should determine what knowledge is needed to ensure the sustainable development of the organization, set the criteria for it search and the method of acquisition. Functions of organization, motivation and development determine the basic processes of working with organizational knowledge. First, it is the creation or acquisition of knowledge, as well as their storage in a form convenient for subsequent use. New knowledge can be acquired by purchasing (acquiring another firm), leasing (hiring employees, partnership with another firm), developing own personnel. Organizational knowledge can also be created through research, analysis of the experience, and also acquired in the form of patents, equipment, and related technologies. The second most important process is the knowledge sharing. On the other hand, prevention of the knowledge 
leakage that determines core competencies can be very important for the organization [Brown, Duguid, 2001]. Thus, management faces a very difficult task to ensure an adequate combination of freedom and the restriction of the knowledge sharing. The third important process is the use of knowledge by employees in their practical.

The goal of management is not only to build an organizational structure that supports the effective implementation of these processes but also to motivate employees to acquire, share and use knowledge in their work, develop their respective skills, which is achieved through the creation of an appropriate organizational context.

According to [Drucker, Maciariello, 2008], another function of management is to evaluate the results achieved and the people who achieved them. In the case of knowledge management, this means determining the benefits that obtained from knowledge, as well as removing from use that knowledge that is no longer needed or obsolete. In [Choo, 2006] it was noted that organizations use knowledge to achieve three different but complementary goals: detecting changes in the external environment, the creation of innovations, and making decisions.

The first goal corresponds to the view of the organization as an information mechanism, according to which it processes information coming from external sources, to adapt to new circumstances. [Hsu, Sabherwal, 2012] also indicate that the knowledge is associated with the dynamic capabilities, which are determined by potential to detect and exploit the seized opportunities [Teece, 2009]. To use these opportunities, the organization must appropriately transform and reconfigure resources and operational routines. Note that the control of transformation is an integral element, the positive effect of the knowledge will not be obtained without realizing the changes.

The second goal is not only to change the ways of thinking and acting, but also to actively influence the external environment through changing the principles of organi- zational design, the development of new products, the creation of new business models, i.e. various innovations. From this point of view, the ability of the organization to manage changes is also very important factor, since the effect of innovations will be obtained only when they are realized in practice. The relation between KM and innovation is confirmed by many theoretical and empirical works [Andreeva, Kianto, 2012; Hsu, Sabherwal, 2012].

The third goal of using organizational knowledge according to [Choo, 2006] is to provide decision-makers with the information they need. However, the knowledge also provides other ways for creating value. For example, [Penrose, 1959] noted that the knowledge of employees allows more efficient use of the company's material resources.

In [Hsu, Sabherwal, 2012] the authors proposed that the three listed factors (dynamic capabilities, innovation, and internal efficiency) are mediators that provide the impact of knowledge management on the effectiveness of the organization.

To conclude the short review of knowledge management literature, we can summarize the following. Organizational knowledge is a resource that, like other resources, is created, stored and used, but its peculiarity is that usage does not reduce the quantity. The availability of this resource should positively influence the effectiveness of the organization, as it improves dynamic capabilities, is a source of innovation and improves the quality of decisions. So, knowledge very closely relates organizational changes in a broad sense, including both evolutionary (incremental) and transformational (radical) processes, managerial and technological innovations, changes managed by top management and initiated at the operational level, covering both the organization as a whole and its subsystems. From this point of view, the most important factor is not only the organization's ability to receive and accumulate knowledge, but also to implement knowledge in the changes. Therefore, change management should be 


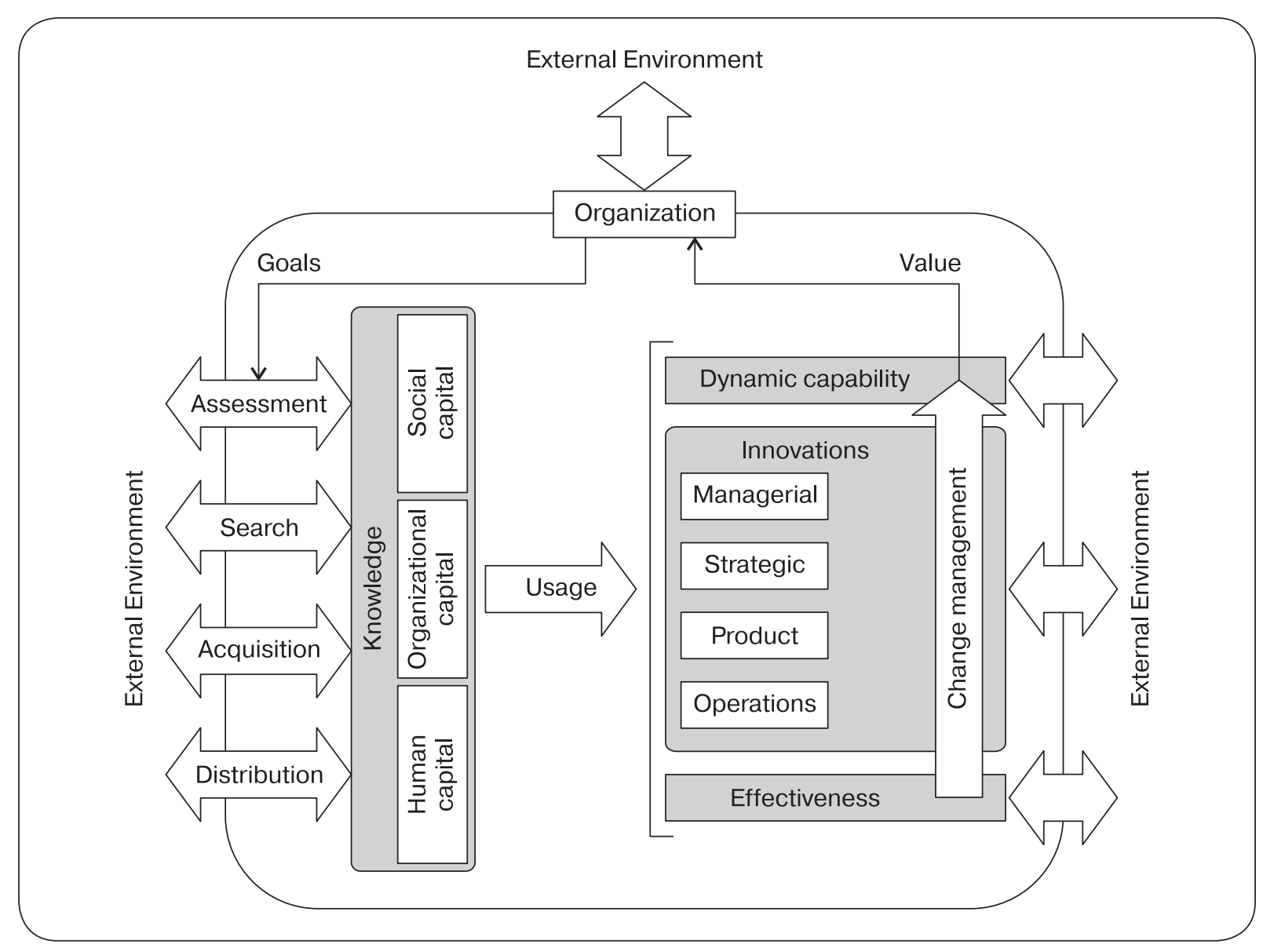

Fig. 1. Knowledge management and change management in organization

considered in conjunction with knowledge management [Zelenkov, 2016].

Researchers consider two types of relationships between knowledge and change. The first line of research considers knowledge as a source of change [Le Bas, Mothe, NguyenThi, 2015; Centobelli, Cerchione, Esposito, 2018]. The second line of research studies how organizational change elements influence knowledge [Park, Kim, 2015; Rusly, Corner, Sun, 2012; Rusly, Sun, Corner, 2015] or reconceives of changes as s process of knowledge generation [Balogun, Jenkins, 2003; Bess, Perkins, McCown, 2010]. It should be noted that these approaches do not contradict each other. According to the definitions by [Nonaka, Takeuchi, 1995; Davenport, Prusak, 1998], knowledge is primarily an experience that allows solving known problems. When existing knowledge is not enough, the subject (human or group of humans that should make a decision) requests additional information to relieve the uncertainty of the current situation. Thus, the processes of change and the acquisition of knowledge can be viewed as a continuous cycle of learning and adaptation to a changing situation [Jacobs, 2017].

The discussion presented above makes it possible to propose a model what links organizational knowledge and organizational change together (Fig. 1). Several studies designating organizational knowledge as intellectual capital have underscored the notion that knowledge is utilized through different approaches in an organization. The authors of these studies consider intellectual capital 
to be the sum of all knowledge that organizations utilize for competitive advantage [Subramaniam, Youndt, 2005].

Researchers have identified three prominent aspects of IC: human, organizational, and social capital. Human capital is defined as knowledge, skills, and abilities residing with and utilized by individuals, whereas organizational capital is the institutionalized knowledge and codified experience residing within and utilized through databases, patents, manuals, structures, systems, and processes [Subramaniam, Youndt, 2005]. The third aspect, social capital, is defined as the knowledge embedded within, available through, and utilized by interactions among individuals and their networks of interrelationships [Nahapiet, Ghoshal, 1998].

According to proposed model, intellectual capital is viewed as a "store" of all elements of the organizational knowledge.

Flows that replenish the IC are the search, acquisition and sharing that "transfer" knowledge from the external environment to the organization [Massingham, 2014]. Note that even the creation of own knowledge (here considered as a sub process of the acquisition process) also generally occurs in interaction with the external environment.

The assessment of knowledge is related to the definition of the relevance of the accumulated IC both explicit and tacit (for example, routines). As a result of the assessment, the process of searching and acquiring new knowledge (e.g. training, research or optimization of routines) or disposal of outdated knowledge (the most obvious example is the abolition of obsolete standards and instructions) can be initiated.

The process of using IC does not reduce its level, but it also creates value for the organization through the application of knowledge in daily activities and the corresponding increase in internal efficiency, the generation of innovations, and the enhancement of the organization's dynamic capabilities [Denford, 2013].

These actions can be directed to both the external environment and the transformation of the organization itself. Note, however, that value creation is associated with the implementation of changes that are proposed as a result of the use of knowledge, therefore the process of change management plays a crucial role. The value of knowledge is transformed into productivity and effectiveness at the organization level. Considering its strategic perspectives and interacting with a changing environment, the organization forms the requirements to the knowledge that it must possess for successful achievement. This sets the goals of knowledge management, which are implemented through the assessment process.

\subsection{The role of change management}

In the previous section, it was stated that knowledge is very closely linked with changes in the organization. Therefore, the ability to implement change is the most important factor that determines the creation of value based on knowledge and the effectiveness of KM processes [Rusly, Corner, Sun, 2012].

Change management also refers to critical management technologies, as the modern business environment is highly turbulent, therefore, a successful organization must respond to emerging challenges in a timely manner [Todnem By, 2005]. CM can be defined as "the process of continuous updating of the management tools, structure and capabilities of the organization to meet the constantly changing needs of external and internal consumers" [Moran, Brightman, 2001]. Organizational changes vary in frequency of occurrence, source, and scale [By, 2005], and change is an inherent feature of the organization. In view of the unpredictable nature of changes, the need for CM arises ad hoc, this practice tends to be reactive and continuous, changes are often triggered by organizational crises. However, [Balogun, Hope Hailey, 2004] cite data that about 70\% of all change programs do not end with success. This is due to the fact that the theoretical aspects of change management are not yet fully developed, the various models often contradict each other and are poorly

RMJ 16 (4): 513-536 (2018) 
supported by empirical results [Todnem By, 2005].

In their turn, [Graetz, Smith, 2010] compared 10 very broad interpretations of organizational changes, including those based on psychological, rational, institutional, resource, systemic and other approaches. Their main conclusion is that a successful organization, should be based on a modular structure and support the strategy of ambidexterity.

Researchers also distinguish a different number of phases in process of implementing changes. Summarizing their results, it can be assumed that in any process of change three important stages are distinguished [Armenakis, Harris, 2009]:

- recognition of the need for a change (diagnosis);

- preparation for change (creating readiness);

- implementation of change (change adoption and institutionalization).

The term "change readiness" is proposed by [Armenakis, Harris, Field, 1999] as the opposite of the concept of "resistance". Readiness is formed on the basis of communications, wide awareness and due to the active involvement of employees. This allows to assess the possibility of implementing changes, consolidate and focus efforts, assess the adequacy of resources and the potential feasibility of change. CR motivates employees to be persistent and committed to the change process. Consequently, change readiness is a critical element that shapes the outcomes of change initiative in organization [Rusly, Sun, Corner, 2015].

Change readiness combines the properties of state and process. A state of readiness means that there is a general conviction that the proposed change is necessary and feasible. Readiness as a process includes such activities as recognizing a situation in which a change is necessary, estimating the costs and benefits of implementing a change, scheduling a change.

Many researchers [Armenakis, Harris, 2009; Weiner, 2009; Rusly, Corner, Sun, 2012] note that change readiness is mani- fested at two levels: individual (motivation, competence, etc.) and organizational (culture, climate, availability of resources, etc.). According to a theoretical analysis by [Rusly, Corner, Sun, 2012] change readiness determines the effectiveness of knowledge management. It follows that the change readiness is closely related to knowledge both at the individual and organizational levels. Thus, it can be argued that knowledge management and change management are complementary practices. According to this, we can formulate main hypothesis of our research: only joint implementation knowledge management and change management will have the maximum effect in the effectiveness of the organization.

\subsection{Knowledge management and change management in practice}

Since 1993, Bain \& Company has been publishing results of bi-annual research on the use of various management tools [Rigby, 2001; 2015], which include the most important concepts and strategies, such as a balanced scorecard, benchmarking, big data, etc. Each time, 25 most common technologies are selected. The selection of managerial tools is based on an analysis of the scientific and business literature, consultations with top managers and professors of the leading business schools, and also on the basis of the dynamics of indicators of those concepts that were chosen for previous studies. Data are collecting among the leading companies around the world, more than 1000 companies participated in the latest researches. Among the key characteristics of the various instruments that are surveyed: the share of companies using this tool (as a percentage of the total number of surveyed) and the degree of satisfaction with it (on a 5-point scale).

The definition of knowledge management used by Bain \& Company is broadly consistent with the definition used here and means the development of systems and processes for the acquisition and use of intellectual capital with the goal of creating unique key competencies and gaining competitive 


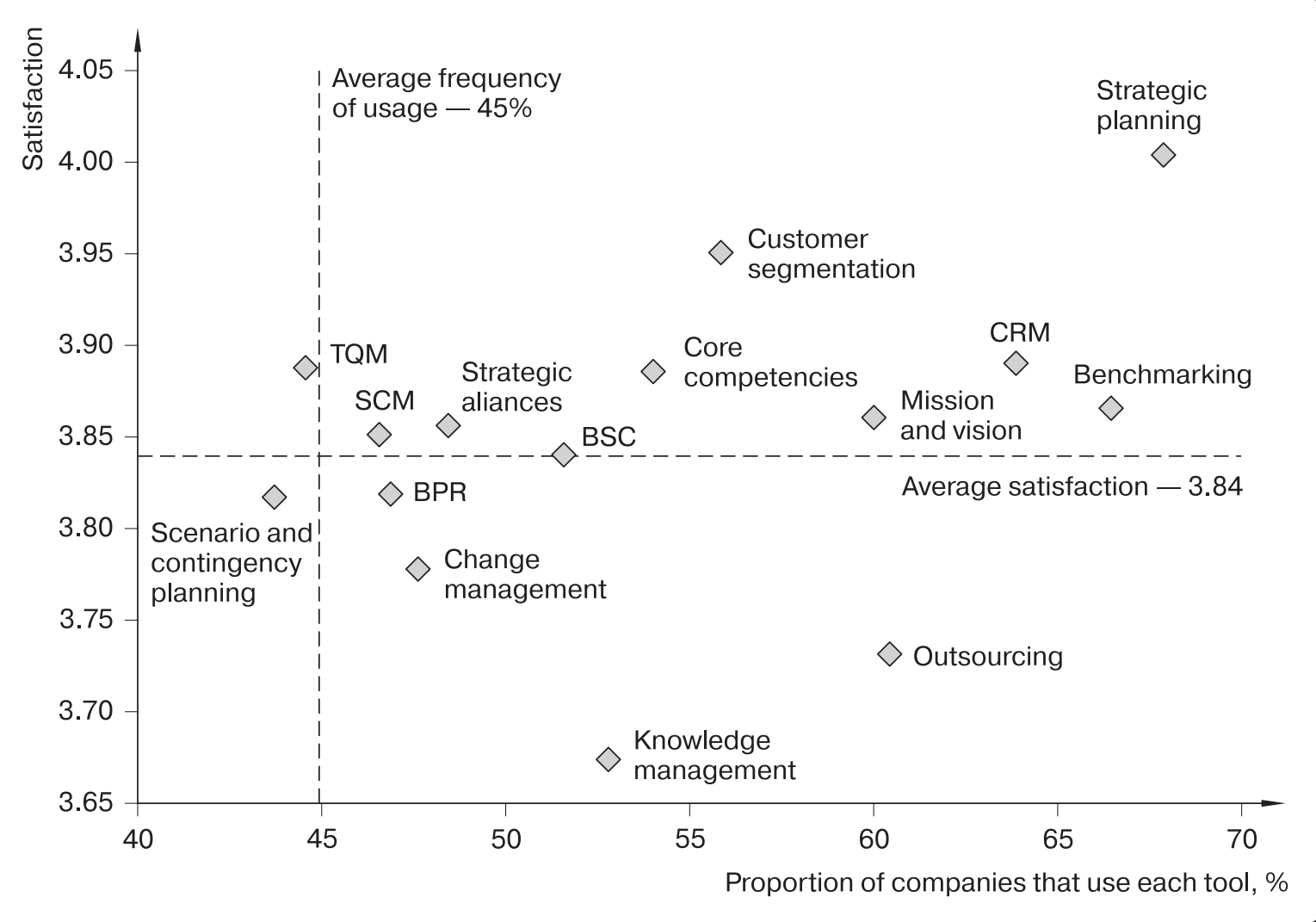

Fig. 2. The frequency of use and level of satisfaction of various management tools in 2003-2015 S o u r ce: according to data at www.bain.com.

advantage [Rigby, 2015]. KM as a management concept was on the list of 25 most used tools until 2011 inclusive. According to the data presented on the Bain \& Company website, the surge in interest to it falls on 2003-2009, when more than $60 \%$ of companies used it. After the crisis of 2008, the use of KM was rapidly declining, and as a result, this tool was excluded from last surveys. At the same time, the indicator of overall satisfaction with the implementation of knowledge management was always below the average for all instruments; moreover, many companies abandoned this concept after years of use [Rigby, 2001].

By the definition of [Rigby, 2015], change management is the ability to implement new processes, i.e. this concept is treated quite narrowly, as aimed at implementing only operational innovations. It should be noted that according to Bain \& Company data, the use of change management has also been decreasing since 2003 when more than $60 \%$ of the surveyed companies applied it. In the 2007-2009 research this technology was not included, satisfaction index with it is also below the average.

Fig. 2 shows the mean values of frequency of use and the degree of satisfaction of the 15 most popular management tools according to Bain \& Company data for 20032015. Vertical and horizontal dashed lines show the average usage and satisfaction for all instruments studied during this period (total 53 tools). As can be seen in Fig. 2, although a large number of companies used $\mathrm{KM}$ and CM, they have been much less satisfied with them than other tools.

Thus, the question arises if knowledge plays such important role, why does the 
practical implementation of KM look so unsatisfactory? According to the hypothesis proposed above, a value of knowledge will be provided only with an appropriate level of change management. Unfortunately, data published by Bain \& Company do not allow to estimate how many companies use these tools together and what their degree of satisfaction is compared to companies using only one of these tools. To obtain such data, additional research is needed.

\section{Knowledge management, change readiness and effectiveness of the organization: hypotheses of the research}

The study of the formulated problem should start from the designation of how we can define and measure the effectiveness of the organization (EO). In most cases, the EO is measured through financial indicators, but this approach is only valid when analyzing the activities of commercial firms. In our study, not only firms participated, but also organizations that provide public services (medicine, education), subsidiaries of state and municipal government, etc. Many researchers measure organizational performance via subjective assessments of parameters such as the ability to develop new products and services; ability to predict the results of actions and assess risks; opportunities to process new information [Gold, Malhotra, Segars, 2001; Lee, Kim, Kim, 2012]. Argyris identified three significant aspects relevant to organizations of any type: goal achievement, optimal use of resources, and adaptation (i.e., change in objectives) to the external environment [Argyris, 1964]. So, we can measure EO via qualitative estimation of these three aspects.

As noted above, change is an inherent feature of any organization, as it is forced to respond to the permanent challenges dictated by the external and internal environment [Moran, Brightman, 2001; By, 2005]. From this, it follows that change readiness is the key factor that determines the effectiveness of the organization. Thus, the first hypothesis of the study can be formulated as follows.

Hypothesis 1. Change readiness positively affects the effectiveness of the organization.

The second factor that makes the organization effective in contemporary conditions is the knowledge [Davenport, Prusak, 1998; Heisig, 2009; Andreeva, Kianto, 2012; Hsu, Sabherwal, 2012; Denford, 2013]. These and many other authors note that velocity and dynamic nature of the new market forces companies to base on knowledge for creating value for a long-term perspective. The key contributions of knowledge management include improved ability to innovate, the rapid development of new products and services, responsiveness to market change, and reduced redundancy of information. This allows us to formulate the second research hypothesis.

Hypothesis 2. Knowledge management has a positive impact on the effectiveness of the organization.

It was also noted above that the readiness for change is manifested at two levels: individual and organizational. The individual level is determined by the motivation of the employees to propose changes and to participate in them, by the presence of the necessary competencies for this. To date, the universally recognized theory of motivation is the theory of self-determination [Gagné, Deci, 2005]. It argues that the behavior of an individual is determined not only by external stimuli (controlled motivation) but also by internal needs (autonomous motivation). It is very important to maintain balance between external stimulation and autonomous motivation because an employee can perceive this as an attempt to control his behavior. Therefore, individual beliefs and expectations should be supported by appropriate development of the organizational level, which includes corporate culture, leadership, structure, availability and accessibility of resources for change, 
i.e. technical, structural and cultural factors of the organization as a whole. Thus, the organizational level largely determines the individual level.

Similar considerations are also valid for knowledge management because in this area of activity individual and organizational levels can also be distinguished. Based on the theory of self-determination, [Wang, Hou, 2015] carried out an empirical study of factors influencing the propensity to share knowledge. Their results show that autonomous motivation is the most significant factor that also serves as a mediator for explicit and implicit rewards. Therefore, the creation of a context focused primarily on maintaining autonomous motivation is the most important factor for success in knowledge management.

In [Lee, Kim, Kim, 2012] the researchers explored the impact of various aspects of $\mathrm{KM}$ on organizational performance. According to their results, knowledge infrastructure determines the quality of knowledge management processes. The infrastructure of knowledge, in this case, is understood as technical, structural and cultural factors (i.e. this concept is similar to the notion of "organizational level"), which maximizes the return on social capital.

Table 1 lists the factors that determine support for knowledge management and change readiness at the individual and organizational levels identified by different authors. It follows from these data that the factors determining both perspectives (KM and CR) coincide in many respects. Thus, we can define individual support as the motivation of employees to acquire and use knowledge, openness to change and readiness to participate in them. Organizational support is the ability of an organization to create a culture, context and practices that motivate employees to rely on knowledge and be ready to change.

Only the simultaneous development of both these components will ensure the expected return. These considerations allow us to formulate the following hypotheses:
Hypothesis 3a. Organizational support has a positive effect on change readiness. Hypothesis $3 b$. Organizational support has a positive effect on knowledge management.

Hypothesis 4a. Individual support positively affects change readiness.

Hypothesis 4b. Individual support has a positive effect on knowledge management. Hypothesis 5. Organizational support positively affects the individual support.

According to the model of knowledge management presented in Fig. 1, knowledge is realized through various types of changes, so the change readiness is a factor that contributes to increasing efficiency via knowledge usage. According to a theoretical analysis by [Rusly, Corner, Sun, 2012], change readiness determines the effectiveness of knowledge management, however, as it was discussed above, knowledge and changes are products of the continuous process of adaptation and learning. Knowledge determines the ability of the organization to detect the need for change, to propose changes and to implement them. On this basis, we state last hypothesis.

Hypothesis 6. The better the knowledge management is implemented, the higher change readiness of the organization.

Fig. 3 shows a preliminary research model based on the proposed hypotheses. Used designations: $E$ is the organization efficiency, $C R$ is the change readiness, $K M$ is the knowledge management, IND is the individual support, $O R G$ is the organizational support.

\section{Survey organization}

The factors listed in Fig. 3 (effectiveness of organization, change readiness, etc.) are not sufficiently well defined and do not allow to design model for their direct measurement. So, we will use PLS-SEM technique that allows to build measurement model and testing the relation between constructs.

The structural model is shown in Fig. 3. To design a measurement model, an analysis 
Factors that determine individual and organizational support of knowledge management and change readiness

\begin{tabular}{|c|c|c|}
\hline Construct & Knowledge management perspective & Change readiness perspective \\
\hline $\begin{array}{l}\text { Individual } \\
\text { support }\end{array}$ & $\begin{array}{l}\text { Self-efficacy, openness to experience, per- } \\
\text { ceived support from colleagues and } \\
\text { supervisors and perceptions of rewards } \\
\text { associated with sharing knowledge } \\
\text { [Cabrera, Collins, Salgado, 2006]. } \\
\text { Combination of four competences: } \\
\text { cognitive, information, social and } \\
\text { learning [Wright, 2005]. } \\
\text { Team members' knowledge, skills, } \\
\text { experience, background, perceptions, } \\
\text { attitudes and values [Ghobadi, 2015] }\end{array}$ & $\begin{array}{l}\text { Cognitive ability, conscientiousness, emotion- } \\
\text { al stability, mastery goal orientation and } \\
\text { self-efficacy, metacognition [Jundt, Shoss, } \\
\text { Huang, 2015]. } \\
\text { Individual's characteristics, flexibility, } \\
\text { adaptability [Maynard, Kennedy, Sommer, } \\
2015 \text { ]. } \\
\text { Individual's knowledge, skills, and abilities } \\
\text { and their alignment with the change [Holt, } \\
\text { Vardaman, 2013] }\end{array}$ \\
\hline $\begin{array}{l}\text { Organizational } \\
\text { support }\end{array}$ & $\begin{array}{l}\text { The significant drivers to knowledge } \\
\text { sharing are: enjoy helping others, } \\
\text { monetary rewards, management } \\
\text { support [Razmerita, Kirchner, } \\
\text { Nielsen, 2016]. } \\
\text { Workplace contexts that shape individual } \\
\text { learning and their opportunities for } \\
\text { learning [Manuti et al., 2015]. } \\
\text { Organizational factors such as cultural } \\
\text { values, leadership and human resource } \\
\text { practices [Donate, Guadamillas, 2011]. } \\
\text { Organizational practices drivers, which } \\
\text { refer to existing organizational norms, } \\
\text { communication networks, and prac- } \\
\text { tices [Ghobadi, 2015] }\end{array}$ & $\begin{array}{l}\text { Job, task, and contextual factors: leader } \\
\text { support, transformation leadership [Jundt, } \\
\text { Shoss, Huang, 2015]. } \\
\text { Supportive context, organization climate, } \\
\text { resource access [Maynard, Kennedy, } \\
\text { Sommer, 2015]. } \\
\text { Perceived organizational support, or employee } \\
\text { perceptions of the degree to which } \\
\text { the organization values their contributions } \\
\text { [Gigliotti et al., 2018]. } \\
\text { Discrepancy (an understood difference } \\
\text { between the current state or practice and } \\
\text { a more desirable state), support climate } \\
\text { (sufficient tangible and an encouraging } \\
\text { intangible environment to support imple- } \\
\text { mentation), facilitation strategies (a set } \\
\text { of clearly articulated goals and objectives } \\
\text { that are supported by a detailed implemen- } \\
\text { tation plan) [Holt, Vardaman, 2013] }\end{array}$ \\
\hline
\end{tabular}

of the literature was carried out and questions were developed that made it possible to adequately assess the factors studied. Since single item measures generally frame concepts narrowly, the measurement of the selected factors was done through multipleitem measures. Multiple-item measures are generally thought to enhance confidence that the measurement of the variables will be more consistent [Gold, Malhotra, Segars, 2001; Schwab, 2013]. In addition, variables are measured with Likert-type scales that provide the advantage of standardizing and quantifying relative effects.

Where available, constructs were measured using tested questions from prior studies or were modified to enhance the validity of the scales used. Questions to assess organizational effectiveness were taken from [Gold, Malhotra, Segars, 2001], who identified its key components. Such components may include improved ability to innovate, improved coordination of efforts, rapid commercialization of new products, the ability to anticipate surprises, and so on. In total, the authors proposed fourteen items to measure organizational effectiveness. These items were redesigned to suit theoretical (goal achievement, optimal use of resources, and adaptation to the external environment [Argyris, 1964]) and practical (continuous update of products, services, and processes 


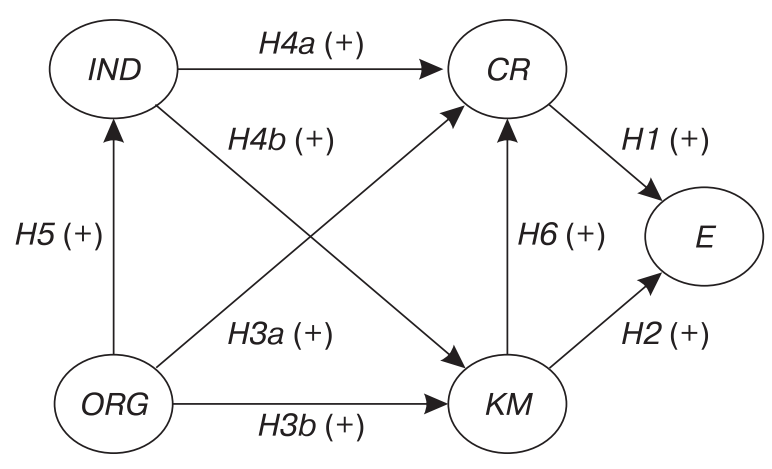

Fig. 3. Research model

[Bukowitz, Williams, 1999]) assessments. Measurement of knowledge management is based on results of [Gold, Malhotra, Segars, 2001; Lin, Huang, 2008] that were reviewed to take in consideration theoretical statements of [Lotti Oliva, 2014; Massingham, 2014]. These measurements mainly reflect presence of informal issues of KM. Measurement of change readiness is based on [Weiner, Amick, Lee, 2008; Rusly, Corner, Sun, 2012; Rafferty, Jimmieson, Armenakis, 2013].

As it was defined in Section 2, individual support (IND) reflects the motivation of employees. Therefore, questions that help to measure their intention to share knowledge to follow changing organizational goals was included. Organizational support (ORG) is the ability of an organization to create a culture, context and practices that motivate employees to acquire and use knowledge in changes. So, two items that focus on organizational change, and two items that focus on knowledge management were designed to measure this construct including question $\mathrm{ORG}_{3}$ which reflects presence of formal practices.

As a result, a questionnaire was designed, which included 4 questions for evaluating each construct - a total of 20 questions. Each question was formulated in a positive affirmative form (e.g. "we pay special attention to the work with personnel in the changes"), the interviewee had to choose the answer from the range defined by the 5-step Likert scale (from 1 - "completely disagree" to 5 - “completely agree"). Constructs and questions for their measurement are presented in Table 2.

In addition, the questionnaire included questions about the characteristics of the organization, which, according to preliminary estimation, could significantly affect the factors studied, namely: the type of activity (business, state and municipal management, public services i. e. education, medicine, etc.), size (number of employees), who the main owner is (state or private investors), as well as the date of establishment of the organization. Business and management in Russia have changed since the 1990, as the country has transitioned from the centrally planned Soviet system to a mainly market economy [Puffer, McCarthy, 2011], and with this change, Russian people have learned new knowledge and skills with new technological devices and instruments, that brought innovation and organized new production process. So, by the creation date, the organizations were divided into two groups. The first group included organizations created during the times of the Soviet Union (until 1991), probably, they inherited hierarchical structures with a high degree of bureaucratization. The second group included organizations created after 1991, probably they use more modern forms of management. 
Constructs and measures

\begin{tabular}{|c|c|c|c|c|}
\hline Construct & Description & Measures & Survey question & References \\
\hline \multirow[t]{4}{*}{ IND } & \multirow[t]{4}{*}{$\begin{array}{l}\text { Individual } \\
\text { support }\end{array}$} & $I N D_{1}$ & $\begin{array}{l}\text { Our employees always strive to perform their } \\
\text { duties as best as possible }\end{array}$ & \multirow{4}{*}{$\begin{array}{l}\text { [Armenakis, } \\
\text { Harris, Field, } \\
\text { 1999; Lotti Oliva, } \\
\text { 2014; Rusly, } \\
\text { Corner, Sun, } \\
\text { 2012] }\end{array}$} \\
\hline & & $I N D_{2}$ & $\begin{array}{l}\text { Each our employee is aware of how his knowl- } \\
\text { edge influences the work of colleagues and } \\
\text { the effectiveness of the organization }\end{array}$ & \\
\hline & & $I N D_{3}$ & $\begin{array}{l}\text { Employees believe that the sharing of their } \\
\text { knowledge does not reduce their importance for } \\
\text { the organization }\end{array}$ & \\
\hline & & $I N D_{4}$ & $\begin{array}{l}\text { Our employees highly appreciate the opportu- } \\
\text { nity to contribute to the organization success }\end{array}$ & \\
\hline \multirow[t]{4}{*}{$\overline{O R G}$} & \multirow{4}{*}{$\begin{array}{l}\text { Organizational } \\
\text { support }\end{array}$} & $O R G_{1}$ & Top-managers actively participate in changes & \multirow{4}{*}{$\begin{array}{l}\text { [Hsu, Sabherwal, } \\
\text { 2012; } \\
\text { Massingham, } \\
\text { 2014; Rusly, } \\
\text { Corner, Sun, } \\
\text { 2012] }\end{array}$} \\
\hline & & $\mathrm{ORG}_{2}$ & $\begin{array}{l}\text { Top-managers participate in the analysis } \\
\text { of results and lessons of changes }\end{array}$ & \\
\hline & & $O R G_{3}$ & $\begin{array}{l}\text { We use both qualitative and quantitative } \\
\text { metrics of knowledge }\end{array}$ & \\
\hline & & $O R G_{4}$ & $\begin{array}{l}\text { Senior executives clearly demonstrate } \\
\text { the importance they attach to knowledge }\end{array}$ & \\
\hline \multirow[t]{4}{*}{$\overline{C R}$} & \multirow[t]{4}{*}{$\begin{array}{l}\text { Change } \\
\text { readiness }\end{array}$} & $C R_{1}$ & $\begin{array}{l}\text { We pay special attention to work with personnel } \\
\text { during the changes }\end{array}$ & \multirow{4}{*}{$\begin{array}{l}\text { [Weiner, Amick, } \\
\text { Lee, 2008; Rusly, } \\
\text { Corner, Sun, } \\
\text { 2012; Rafferty, } \\
\text { Jimmieson, } \\
\text { Armenakis, 2013] }\end{array}$} \\
\hline & & $C R_{2}$ & $\begin{array}{l}\text { We always try to find and solve the problem } \\
\text { that is the reason for incidents in different } \\
\text { areas }\end{array}$ & \\
\hline & & $C R_{3}$ & $\begin{array}{l}\text { We always can define the boundaries } \\
\text { of the proposed change }\end{array}$ & \\
\hline & & $C R_{4}$ & $\begin{array}{l}\text { We always create an effective communication } \\
\text { environment for analyzing and planning } \\
\text { changes }\end{array}$ & \\
\hline \multirow[t]{4}{*}{$\overline{K M}$} & \multirow[t]{4}{*}{$\begin{array}{l}\text { Knowledge } \\
\text { management }\end{array}$} & $K M_{1}$ & $\begin{array}{l}\text { We participate in various research to under- } \\
\text { stand how much we need new knowledge }\end{array}$ & \multirow{4}{*}{$\begin{array}{l}\text { [Gold, Malhotra, } \\
\text { Segars, 2001; } \\
\text { Lin, Huang, } \\
2008 ; \\
\text { Lotti Oliva, 2014; } \\
\text { Massingham, } \\
\text { 2014] }\end{array}$} \\
\hline & & $K M_{2}$ & $\begin{array}{l}\text { Knowledge sharing is officially encouraged in } \\
\text { our organization and time is allocated for this }\end{array}$ & \\
\hline & & $K M_{3}$ & $\begin{array}{l}\text { We carefully study any new idea, irrespective } \\
\text { of who suggested it }\end{array}$ & \\
\hline & & $K M_{4}$ & $\begin{array}{l}\text { We realize that knowledge is a resource } \\
\text { on the basis of which our organization creates } \\
\text { a value for the consumer }\end{array}$ & \\
\hline \multirow[t]{4}{*}{$E$} & \multirow[t]{4}{*}{ Effectiveness } & $E_{1}$ & $\begin{array}{l}\text { We always strive to make the best use } \\
\text { of resources }\end{array}$ & \multirow{4}{*}{$\begin{array}{l}\text { [Argyris, 1964; } \\
\text { Bukowitz, } \\
\text { Williams, 1999; } \\
\text { Gold, Malhotra, } \\
\text { Segars, 2001] }\end{array}$} \\
\hline & & $E_{2}$ & $\begin{array}{l}\text { We are constantly reducing any types of losses: } \\
\text { defects, useless work, downtime, excess stocks, } \\
\text { etc. }\end{array}$ & \\
\hline & & $E_{3}$ & $\begin{array}{l}\text { We always respond in time to any events } \\
\text { in the external environment }\end{array}$ & \\
\hline & & $E_{4}$ & $\begin{array}{l}\text { We continuously update products, services, and } \\
\text { processes }\end{array}$ & \\
\hline
\end{tabular}


Table 3

Distribution of surveyed organizations

\begin{tabular}{|c|c|c|c|c|}
\hline & Number of organizations & Share in the sample & $F$-value & $F$-critical \\
\hline \multicolumn{5}{|c|}{ Activity } \\
\hline Business & 69 & 0.67 & \multirow[t]{3}{*}{1.090} & \multirow[t]{3}{*}{3.095} \\
\hline Government and municipal administration & 20 & 0.19 & & \\
\hline Public services & 14 & 0.14 & & \\
\hline \multicolumn{5}{|c|}{ Size } \\
\hline Less than 100 employees & 23 & 0.22 & \multirow[t]{4}{*}{1.966} & \multirow[t]{4}{*}{2.705} \\
\hline 100-500 employees & 32 & 0.31 & & \\
\hline 501-1000 employees & 17 & 0.17 & & \\
\hline More than 1000 employees & 31 & 0.30 & & \\
\hline \multicolumn{5}{|c|}{ Main owner } \\
\hline State & 40 & 0.39 & \multirow[t]{2}{*}{4.729} & \multirow[t]{2}{*}{3.943} \\
\hline Private investors & 63 & 0.61 & & \\
\hline \multicolumn{5}{|c|}{ Establishment data } \\
\hline Before 1991 & 42 & 0.41 & \multirow[t]{2}{*}{0.039} & \multirow[t]{2}{*}{3.943} \\
\hline After 1991 & 61 & 0.59 & & \\
\hline
\end{tabular}

The study was conducted in two stages. The first one was conducted in OctoberNovember 2015, the second in February 2017. References to the questionnaire, implemented using Google Forms, were distributed through professional communities (financial directors, HR directors, IT directors) in the Facebook and off-line professional conferences. In total, at the first stage, 92 responses were received from various organizations, 83 of them were found to be valid. At the second stage, 36 filled questionnaires were received, 20 of them were filled correctly. Thus, 103 organizations participated in the study. Their distribution is shown in Table 3 .

An essential issue of empirical research is the determination of the minimum number of samples. The thumb rule is widely used, according to which it is necessary to have at least 10 observations per each independent variable. In our case, because we use the reflective model of measurement, it is necessary to consider only the structural model and choose the construct that has the greatest number of incoming connections, i. e. the largest number of other latent variables affecting it [Chin, 1998]. As it follows in Fig. 3, this is the latent variable $C R$, which is influenced by three other constructs. Thus, according to [Chin, 1998], the data set should include at least 30 samples.

After the data collection, the dataset was analyzed to estimate the errors that may be caused, firstly, by the difference in the procedures of data collection, and, secondly, by the potential bias in respondents set. For this, a two-sample $t$-test was performed for the two subsanples collected in 2015 and in 2017. Similar procedures were conducted for two datasets, first of which included all questionnaires filled correctly, while the second one consisted of all questionnaires that were rejected because of errors in the filling. The results showed that there was no statistically significant difference between these groups of data, and therefore there are no errors related to data collection and bias of respondents.

In [Little, Rubin, 2014] authors noted that statistical analysis often suggests that errors in measuring the variables in the

RMJ 16 (4): 513-536 (2018) 
sample are independent of their values. To test this assumption, [Little, Rubin, 2014] calculated the MCAR statistics. The results showed that the errors are random and do not significantly affect the values of the variables.

An important aspect of quantitative research is the estimation of the common method variance [Podsakoff, MacKenzie, Podsakoff, 2012]. The source of such error may be unaccounted factors that determine the variation of the investigated variables and, consequently, the correlation between them. Therefore, factor analysis without rotation was performed, as a result, 6 factors explaining $58.2 \%$ of variation were found, with the first factor accounting for only $19.4 \%$ of the variation. From this, we can conclude that there is no single factor determining the displacement of the results obtained. In addition, the maximum correlation between the variables in the sample is $\mathbf{0 . 6 7 8}$, which does not exceed the critical value of 0.9 . Thus, the results of these tests indicate that the overall bias of the method is not a significant problem in this study.

To assess the impact of the selected characteristics (activity, size, age, ownership) on the effectiveness of the organization, a single-factor ANOVA was carried out for each of them. As the dependent variable, the average effectiveness

$$
\bar{E}_{j}=\sum_{i=1}^{4} E_{i j}
$$

was taken, here $E_{i j}$ is the $j$-th respondent's estimation of the answer to the $i$-th question regarding the effectiveness of the organization. The calculated and critical values of Fisher's $F$-test are given in Table 3 . It follows from the data given that there are two groups in the dataset, the average effectiveness of which are statistically significantly different. The separating variable is the type of the organization owner, the effect of all other characteristics is not significant. Thus, the analysis of the model should be carried out separately for each type of owner of the organization.

\section{Results}

Numerical verification of the model shown in Fig. 3 were conducted on the base of software package SmartPLS v.3 [Ringle, Wende, Becker, 2015]. As noted above, the data for the two types of organization owners (state and private investors) are different, therefore separate models were built for each type of owner.

Before analyzing modeling results, it is necessary to check the reliability of the models. First, we need to test the convergent validity of the measurement model, which requires assessing factor loadings, composite reliability $(\mathrm{CompR})$, and the average variance extracted $(A V E)$ [Hair et al., 2013], see Table 4.

The critical value of factors loadings $\lambda_{j k}$ is 0.7 , which means that the construct explains at least $50 \%$ of the variation of the corresponding indicator. As shown in Table 4, this condition is met with one exception, for the indicator $E_{4} \lambda_{j k}=0.697$. However, this indicator was left in the model, since the corresponding values of CompR and $A V E$ indicate a high quality of the measurement model. The CompR value shows how much of the construct variation is reflected by its indicators, so it should not be less than 0.7. AVE measures the total variation of the indicators, explained by their construct, this value should not be less than 0.5. As follows from Table 4, all these conditions are met.

The next step is to check the discriminant validity of the measurement model, it is necessary to sure that connection of each indicator with the "own" construct is much stronger than with all the others. This can be estimated from the values of cross loadings, the value of coefficient $\lambda_{j k}$ for the indicator and the construct which it reflects should be greater than the analogous coefficients for this indicator and all other constructs in the model. This condition is met. In addition, the correlation between the factors should be less than the square root of the $A V E$ value (see Table 5, where the correlation 
Table 4

Convergent validity of the measurement model

\begin{tabular}{|c|c|c|c|c|c|c|c|}
\hline \multirow{2}{*}{ Construct } & \multirow{2}{*}{ Measured indicator } & \multicolumn{3}{|c|}{ State-owned organizations } & \multicolumn{3}{|c|}{ Private organizations } \\
\hline & & $\lambda_{j k}$ & $A V E$ & CompR & $\lambda_{j k}$ & $A V E$ & CompR \\
\hline \multirow[t]{4}{*}{$I N D$} & $I N D_{1}$ & 0.809 & \multirow[t]{4}{*}{0.701} & \multirow[t]{4}{*}{0.903} & 0.836 & \multirow[t]{4}{*}{0.750} & \multirow[t]{4}{*}{0.923} \\
\hline & $I N D_{2}$ & 0.783 & & & 0.822 & & \\
\hline & $I N D_{3}$ & 0.861 & & & 0.893 & & \\
\hline & $I N D_{4}$ & 0.892 & & & 0.909 & & \\
\hline \multirow[t]{4}{*}{$\overline{O R G}$} & $O R G_{1}$ & 0.809 & \multirow[t]{4}{*}{0.663} & \multirow[t]{4}{*}{0.887} & 0.786 & \multirow[t]{4}{*}{0.709} & \multirow[t]{4}{*}{0.907} \\
\hline & $O R G_{2}$ & 0.901 & & & 0.901 & & \\
\hline & $\mathrm{ORG}_{3}$ & 0.753 & & & 0.836 & & \\
\hline & $O R G_{4}$ & 0.787 & & & 0.841 & & \\
\hline \multirow[t]{4}{*}{$\overline{C R}$} & $C R_{1}$ & 0.846 & \multirow[t]{4}{*}{0.674} & \multirow[t]{4}{*}{0.892} & 0.874 & \multirow[t]{4}{*}{0.739} & \multirow[t]{4}{*}{0.919} \\
\hline & $C R_{2}$ & 0.794 & & & 0.827 & & \\
\hline & $C R_{3}$ & 0.804 & & & 0.863 & & \\
\hline & $C R_{4}$ & 0.837 & & & 0.873 & & \\
\hline \multirow[t]{4}{*}{$K M^{*}$} & $K M_{1}$ & - & \multirow[t]{4}{*}{-} & \multirow[t]{4}{*}{-} & 0.828 & \multirow[t]{4}{*}{0.691} & \multirow[t]{4}{*}{0.899} \\
\hline & $K M_{2}$ & - & & & 0.782 & & \\
\hline & $K M_{3}$ & - & & & 0.885 & & \\
\hline & $K M_{4}$ & - & & & 0.827 & & \\
\hline \multirow[t]{4}{*}{$\bar{E}$} & $E_{1}$ & 0.839 & \multirow[t]{4}{*}{0.618} & \multirow[t]{4}{*}{0.865} & 0.796 & \multirow[t]{4}{*}{0.645} & \multirow[t]{4}{*}{0.879} \\
\hline & $E_{2}$ & 0.772 & & & 0.775 & & \\
\hline & $E_{3}$ & 0.828 & & & 0.835 & & \\
\hline & $E_{4}$ & 0.697 & & & 0.807 & & \\
\hline
\end{tabular}

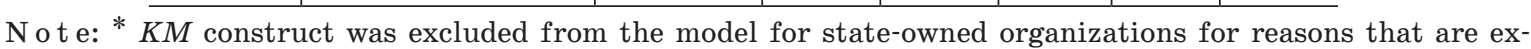
plained below.

Correlations between constructs

Table 5

\begin{tabular}{l|c|c|c|c|c|c|c|c|c|c}
\hline \multirow{2}{*}{ Construct } & $C R$ & $E$ & $I N D$ & KM & ORG & CR & $\boldsymbol{E}$ & IND & KM & ORG \\
\cline { 2 - 11 } & \multicolumn{3}{|c|}{ Private-owned organizations } & \multicolumn{5}{c}{ State-owned organizations } \\
\hline$C R$ & 0.860 & & & & & 0.821 & & & & \\
\hline$E$ & 0.746 & 0.803 & & & & 0.670 & 0.786 & & & \\
\hline$I N D$ & 0.786 & 0.729 & 0.866 & & & 0.715 & 0.706 & 0.837 & & \\
\hline$K M$ & 0.787 & 0.768 & 0.752 & 0.831 & & - & - & - & - & \\
\hline$O R G$ & 0.694 & 0.538 & 0.638 & 0.688 & 0.842 & 0.652 & 0.490 & 0.575 & - & 0.814 \\
\hline
\end{tabular}

N o t e: values of $\sqrt{A V E}$ are indicated in italics.

values are given, and the values of $\sqrt{A V E}$ are indicated on the diagonal and in italics). This condition is also satisfied.

In addition, [Henseler, Ringle, Sarstedt, 2015] suggested another way of measuring the discriminant validity, which they called the HTMT (Heterotrait-Monotrait) ratio of correlations. In a correctly constructed model, the condition $H T M T_{i j} \leq 0.85$ [Kline, 2011] must be met for all factors (see Table 6).

Because formulas linking the constructs in the structural model are regression equations, so the significance of the path coefficients $\beta_{j i}$ can be verified with $t$-statistics. For significant path coefficient must be 
Table 6

HTMT ratios

\begin{tabular}{l|c|c|c|c|c|c|c|c|c|c|c}
\hline \multirow{2}{*}{ Construct } & $\boldsymbol{C R}$ & $\boldsymbol{E}$ & $\boldsymbol{I N D}$ & $\boldsymbol{K M}$ & ORG & $\boldsymbol{C R}$ & $\boldsymbol{E}$ & $\boldsymbol{I N D}$ & $\boldsymbol{K M}$ & ORG \\
\cline { 2 - 11 } & \multicolumn{6}{|c|}{ Private-owned organizations } & \multicolumn{5}{|c|}{ State-owned organizations } \\
\hline$C R$ & & & & & & & & & & \\
\hline$E$ & 0.848 & & & & & 0.810 & & & & \\
\hline$I N D$ & 0.840 & 0.846 & & & & 0.845 & 0.850 & & & \\
\hline$K M$ & 0.847 & 0.817 & 0.844 & & & - & - & - & - & \\
\hline$O R G$ & 0.791 & 0.644 & 0.724 & 0.790 & & 0.776 & 0.605 & 0.674 & - & \\
\hline
\end{tabular}

Table 7

The results of the hypotheses testing

\begin{tabular}{l|c|l|l|c|l|l}
\hline \multirow{2}{*}{ Hypothesis } & \multicolumn{2}{|c|}{ State-owned organizations } & \multicolumn{3}{c}{ Private-owned organizations } \\
\cline { 2 - 7 } & $\boldsymbol{\beta}_{j i}$ & $t$-value & Decision & $\beta_{j i}$ & $t$-value & Decision \\
\hline$H 1: C R \rightarrow E$ & 0.530 & 2.648 & Accept & 0.372 & 3.370 & Accept \\
\hline$H 2: K M \rightarrow E$ & 0.074 & 0.334 & Reject & 0.475 & 4.114 & Accept \\
\hline$H 3 a: I N D \rightarrow K M$ & 0.026 & 0.105 & Reject & 0.528 & 4.108 & Accept \\
\hline$H 3 b: O R G \rightarrow K M$ & 0.441 & 1.921 & Reject & 0.351 & 2.839 & Accept \\
\hline$H 4 a: I N D \rightarrow C R$ & 0.368 & 1.956 & Reject & 0.390 & 4.254 & Accept \\
\hline$H 4 b: O R G \rightarrow C R$ & 0.416 & 2.138 & Accept & 0.202 & 1.600 & Reject \\
\hline$H 5: O R G \rightarrow I N D$ & 0.447 & 2.564 & Accept & 0.638 & 7.620 & Accept \\
\hline$H 6: K M \rightarrow C R$ & 0.021 & 0.084 & Reject & 0.354 & 2.953 & Accept \\
\hline
\end{tabular}

Note s: ${ }^{*} t_{c}=2.042(\propto=0.95)$

** $t_{c}=2.009(\propto=0.95)$.

$t \geq t_{c}(\propto, f)$, where $\propto$ is the significance, $f$ is the number of degrees of freedom, and $t_{c}(\propto, f)$ is corresponding critical value. Statistical significance of path coefficient $\beta_{j i}$ confirms the hypothesis about the impact of construct $F_{i}$ on the construct $F_{j}$; if the path coefficient is not significant, the corresponding hypothesis should be rejected. To test the significance of path coefficients, 500 bootstrapping iterations were performed, the results are presented in Table 7.

As follows from the presented results, the role of knowledge management and changes readiness in ensuring the effectiveness of state-owned and private-owned organizations is radically different. All hypotheses regarding the relationship between knowledge management and other constructs were not confirmed for state-owned organizations. This means that knowledge management has no effect and should be excluded from the model for these organizations. For privateowned organizations, the hypothesis about the impact of organizational development on change readiness was not confirmed.

Based on this analysis, non-significant constructs were removed from the models, the final models are shown in Fig. 4. The constructs are indicated by ellipses, inside which the name of the latent variable and the adjusted value of the coefficient $R^{2}$ are presented. Links between them are indicated by arrows, near which the values of the corresponding path coefficient $\beta_{j i}$ and $t$-values (in parentheses) are given. Note that, after removing the construct $K M$ from the model for state-owned organizations, the link $I N D \rightarrow C R$ corresponding to hypothesis $H 4 a$ became significant, so it was included in the final model. 
(a)

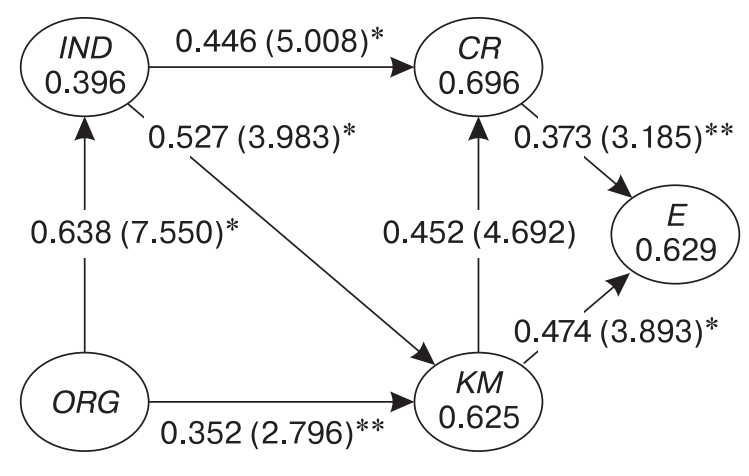

(b)

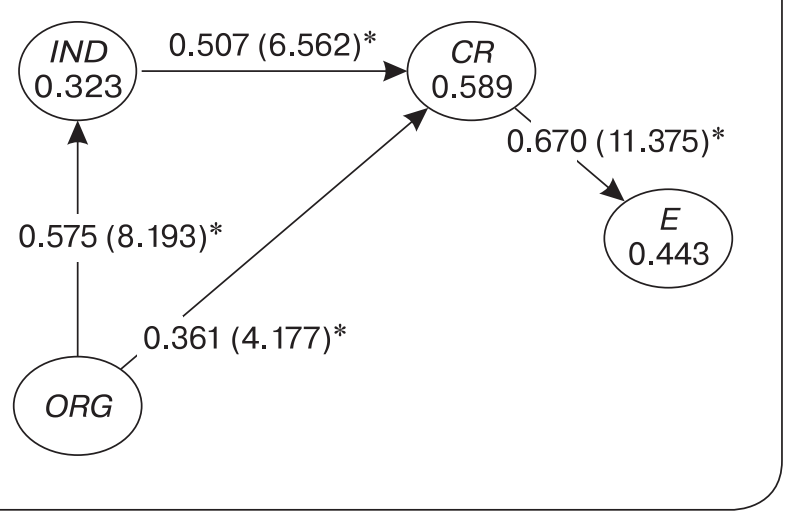

Fig. 4. Final models for private-owned $(a)$ and state-owned $(b)$ organizations

$\mathrm{Notes}$ : in the parentheses the $t$-values are presented, with the corresponding path coefficient $\beta_{j i}$; * $p=0.000, * * p<0.005$.

To assess the quality of the structural model, [Henseler, Hubona, Ray, 2016] recommend the use of a mean-square error $(S R M R)$ value that should not exceed 0.08 . In our case, for the model of state-owned organizations $S R M R=0.073$, for privateowned organizations $S R M R=0.080$, i. e. both models satisfy this condition.

The ability of exogenous factors to explain the variation of the dependent factor can be estimated by the adjusted determination coefficient $R^{2}$ (see Fig. 4). According to [Chin, Peterson, Brown, 2008], values above 0.67 correspond to high predictive abilities, values in the intervals $[0.67 ; 0,33]$ and $[0.33$; $0.19]$ correspond to medium and weak abilities respectively. Models with $R^{2}$ below 0.19 should be avoided. It follows in Fig. 4, the allowable values of the $R^{2}$ for both models are obtained, and the model for privateowned organizations has a higher quality.

\section{Discussion}

The analysis of the obtained results allows to draw important conclusions about the role of knowledge management in Russian organizations.

First, it should be noted that for privateowned organizations (the model in Fig. 4a) the importance of knowledge management and change readiness in ensuring effectiveness has been confirmed. The impact of $K M$ on effectiveness is realized both directly and by ensuring change readiness. In this case, the values of the coefficients $\beta_{j i}$ allow concluding that $K M$ is the dominant factor, and $C R$ serves as only one of many other mediators transmitting its influence. This confirms the total effect $T_{X \rightarrow Y}$ (the sum of products of coefficients $\beta_{j i}$ over all possible paths from the independent variable $X$ to the dependent variable $Y$ in the structural model). For private organizations, total effect $T_{K M \rightarrow E}=0.642$ (it is the sum of products of $\beta_{j i}$ over two path, direct $\left(T_{K M \rightarrow E}\right)$ and indirect $\left(T_{K M \rightarrow C R \rightarrow E}=\right.$ $=T_{K M \rightarrow C R} \cdot T_{C R \rightarrow E}$ ), i.e. $\left.0.474+0.452 \cdot 0.373\right)$; $T_{C R \rightarrow E}=0.373$.

In general, this finding is consistent with the opinion of [Rusly, Corner, Sun, 2012] on the relationship $C R$ and $K M$, but based on the data presented, it can be assumed that change readiness is the result of using enterprise knowledge that confirms the model shown in Fig. 1.

Support at the organizational and individual levels play important role in knowledge management. The direct effect of the individual support is higher, however, the organizational support is important for the formation of individual aspirations and expectations, so the total effects are $T_{I N D \rightarrow K M}=$ 
$=0.527, T_{O R G \rightarrow K M}=0.688$. This is consistent with the results of [Wang, Hou, 2015], which showed that autonomous motivation is a major impetus to the knowledge sharing, as well as the works of [Nahapiet, Goshal, 1998] and many other authors who noted the special role of the organizational context in the creation of personal incentives.

It is worth noting that hypothesis of the direct impact of organizational support on the change readiness is not supported for privateowned organizations, but this relationship is realized via the individual level and knowledge management. Nevertheless, the personal readiness of employees to participate in changes and the availability of the necessary competencies for this are the most important factor of $C R\left(T_{I N D \rightarrow C R}=0.684, T_{O R G \rightarrow C R}=0.595\right.$, $\left.T_{K M \rightarrow C R}=0.452\right)$. This is a significant addition to the views of [Armenakis, Harris, 2009; Weiner, 2009; Rusly, Corner, Sun, 2012] and other authors who noted the importance of both these components.

Secondly, the important result of the study is the fact that knowledge management is not a factor affecting effectiveness in stateowned organizations. Obviously, this cannot be explained only by the high bureaucratization of large state organizations, an unjustifiably large hierarchy of decision-making. A significant number of state-owned organizations that took part in the survey have a relatively small number of employees 1000 or less (see Table 3), so the problem lies in the general approach to management. The results of modeling allow to suggest that such organizations are suppressed individual initiative, decisions are made only by management or require its approval. This way of management, oriented to command-administrative methods, is more typical for Sovietera organizations, but analysis shows that the time of setting up an organization is not a significant factor. This means that stateowned organizations reproduce this way of management at the present time.

In such conditions, the change readiness, unlike private-owned organizations, is maintained mostly through the organizational level $\left(T_{O R G \rightarrow C R}=0.652, T_{I N D \rightarrow C R}=0.507\right)$, less attention is paid to the context that stimulates the initiative of the individuals. Changes are initiated and conducted only by decision of top managers. It can also be concluded that the contribution of the organizational support to effectiveness in stateowned organizations is much higher than in private-owned ones. If for private-owned, the total effects on the effectiveness of the factors of the individual and organizational supports differ only by $8.5 \%\left(T_{I N D \rightarrow E}=0.505\right.$ and $\left.T_{O R G \rightarrow K M}=0.548\right)$, then for state-owned this difference is $28.6 \%\left(T_{I N D \rightarrow E}=0.340\right.$ and $T_{O R G \rightarrow E}=0.437$ ).

This finding contradicts in general to opinion [Klafke et al., 2016] who concluded that Russia, like Brazil and India, has an easier way of converting knowledge in effectiveness because all these countries practice similar KM mechanisms and model the positive experiences of western companies. An analysis of this work shows that the authors made their conclusion on the base of only one source, that studied management practices used by human resource managers to transfer knowledge between Finnish and Russian subsidiaries. Obviously, this is a very special case, multinational corporations (MNC) transfer own managerial practices to various countries [Minbaeva et al., 2003], and they are adapted successfully by means of organizational learning. A relatively small number of works are devoted to the study of the influence of Soviet-style management on the adaptation of modern practices [Puffer, McCarthy, 2011], although it can be quite significant (see, for example, [Michailova, Hutchings, 2006]). In particular, [Rubbo, Picinin, Pilatti, 2018] suggest that Russia, unlike other countries of the BRIC group, having the least amount of KM practices, has the worst economic complexity projection.

\section{Conclusion}

The dynamic nature of the new market forces companies to view their knowledge as a foundation for creating value for a long-term 
perspective. In such circumstances, knowledge very often becomes a source of changes in different areas of the organization activities. On the base of the theoretical analysis, it is assumed here that knowledge can impact significantly on organizational effectiveness only when the organization can identify and realize necessary changes with appropriate speed. From this point of view, change readiness that allows to assess the possibility and feasibility of changes, consolidate and focus efforts, assess the adequacy of resources is a critical element that shapes the outcomes of knowledge management initiative in the organization.

In general, the hypothesis that the increase in effectiveness through the implementation of knowledge management can be achieved only with high change readiness can be considered as confirmed. The model for private-owned organizations (Fig. 4a) proves that change readiness is also a product of enterprise knowledge, i. e. $K M$ is the most important factor in the effectiveness of the organization, and change readiness

\section{REFERENCES}

Ackoff R.L. 1989. From data to wisdom. Journal of Applied Systems Analysis 16: 3-9.

Andreeva T., Kianto A. 2012. Does knowledge management really matter? Linking knowledge management practices, competitiveness and economic performance. Journal of Knowledge Management 16 (4): 617636.

Argyris C. 1964. Integrating the Individual and the Organization. Wiley: N.Y.

Armenakis A.A., Harris S. G. 2009. Reflections: Our journey in organizational change research and practice. Journal of Change Management 9 (2): 127-142.

Armenakis A., Harris S., Feild H. 1999. Making change permanent: A model for institutionalizing change. In: Pasmore W., Woodman R. (eds). Research in Organization Change and Development. Vol.12. Emerald Group Publishing: Bingley, UK; 97-128. is an important supporting factor. This finding has a great implication on practice, managers who bet on the knowledge should focus on the joint and coordinated development of knowledge management and change management practices. Herewith special attention should be paid to the organizational context that supports individual change readiness.

State-owned organizations in Russia are less efficient than private ones [Zelenkov, 2016]. This is due to the fact that knowledge management for them is not the factor of effectiveness. The last in its turn is a consequence of suppression of initiatives at the individual level. Achievement of effectiveness in the sense considered here by stateowned organizations is realized by making changes top-bottom, therefore, the most important factor for them is the support of changes at the organizational level. This is also a significant result for practice, as in Russia the implicit nationalization continues, today the share of the state-owned organizations in the economy is at least $70 \%$.

Balogun J., Hope Hailey V. 2004. Exploring Strategic Change. 2nd ed. Prentice Hall/ Financial Times: Harlow.

Balogun J., Jenkins M. 2003. Re-conceiving change management: A knowledge based perspective. European Management Journal 21 (2): 247-257.

Bess K.D., Perkins D. D., McCown D.L. 2010. Testing a measure of organizational learning capacity and readiness for transformational change in human services. Journal of Prevention \& Intervention in the Community 39 (1): 35-49.

Brown J.S., Duguid P. 2001. Knowledge and organization: A social-practice perspective. Organization Science 12 (2): 198-213.

Bukowitz W.R., Williams R.L. 1999. The Knowledge Management Fieldbook. Financial Times Prentice Hall/Financial Times: London. 
Cabrera A., Collins W.C., Salgado J.F. 2006. Determinants of individual engagement in knowledge sharing. International Journal of Human Resource Management 17 (2): 245-264.

Centobelli P., Cerchione R., Esposito E. 2018. Aligning enterprise knowledge and knowledge management systems to improve efficiency and effectiveness performance: A three-dimensional fuzzy-based decision support system. Expert Systems with Applications 91: 107-126.

Chin W. W. 1998. The partial least square approach for structural equation modeling. In: Marcoulides G. A. (ed.). Modern Methods for Business Research. Lawrence Erlbaum Associates: Mahwah, N. J.; 295-336.

Chin W.W., Peterson R.A., Brown P.S. 2008. Structural equation modelling in marketing: Some practical reminders. Journal of Marketing Theory and Practice 16 (4): 287-298.

Choo C. 2006. The Knowing Organization: How Organizations Use Information to Construct Meaning, Create Knowledge, and Make Decisions. 2nd ed. Oxford University Press: N.Y.

Davenport T.H., Prusak L. 1998. Working Knowledge: How Organizations Manage what They Know. Harvard Business Press: Boston, Massachusetts.

Denford J.S. 2013. Building knowledge: Developing a knowledge-based dynamic capabilities typology. Journal of Knowledge Management 17 (2): 175-194.

Donate M. J., Guadamillas F. 2011. Organizational factors to support knowledge management and innovation. Journal of Knowledge Management 15 (6): 890-914.

Drucker P.F., Maciariello J.A. 2008. Management. HarperCollins: N.Y.

Gagné M., Deci E.L. 2005. Self-determination theory and work motivation. Journal of Organizational Behavior 26 (4): 331362.

Ghobadi S. 2015. What drives knowledge sharing in software development teams: A literature review and classification framework. Information \& Management 52 (1): 82-97.

Gigliotti R., Vardaman J., Marshall D. R., Gonzalez K. 2018. The role of perceived organizational support in individual change readiness. Journal of Change Management; 1-15.

Gold A.H., Malhotra A., Segars A.H. 2001. Knowledge management: An organizational capabilities perspective. Journal of Management Information Systems 18 (1): 185214.

Graetz F., Smith A.C.T. 2010. Managing organizational change: A philosophies of change approach. Journal of Change Management 10 (2): 135-154.

Hair J.F., Hult G. T. M., Ringle C., Sarstedt M. 2013. A Primer on Partial Least Squares Structural Equation Modelling (PLS-SEM). Sage Publications: London.

Heisig P. 2009. Harmonisation of knowledge management - comparing $160 \mathrm{KM}$ frameworks around the globe. Journal of Knowledge Management 13 (4): 4-31.

Henseler J., Hubona G., Ray P. A. 2016. Using PLS path modeling in new technology research: Updated guidelines. Industrial Management \& Data Systems 116 (1): 2-20.

Henseler J., Ringle C. M., Sarstedt M. 2015. A new criterion for assessing discriminant validity in variance-based structural equation modeling. Journal of the Academy of Marketing Science 43 (1): 115-135.

Holt D., Vardaman J. 2013. Toward a comprehensive understanding of readiness for change: The case for an expanded conceptualization. Journal of Change Management 13 (1): 9-18.

Hsu I., Sabherwal R. 2012. Relationship between intellectual capital and knowledge management: An empirical investigation. Decision Sciences 43 (3): 489-524.

Inkinen H. 2016. Review of empirical research on knowledge management practices and firm performance. Journal of Knowledge Management 20 (2): 230-257.

Jacobs R.L. 2017. Knowledge work and human resource development. Human Resource Development Review 16 (2): 176-202.

Jundt D. K., Shoss M.K., Huang J.L. 2015. Individual adaptive performance in organizations: A review. Journal of Organizational Behavior 36 (S1): S53-S71.

Klafke R.V., Lievore C., Picinin C. T., de Francisco A.C., Pilatti L.A. 2016. Primary 
knowledge management practices applied in Brazil, Russia, India and China (BRIC) industries from 2001-2010. Journal of Knowledge Management 20 (4): 812-828.

Kline R. 2011. Convergence of structural equation modeling and multilevel modeling. In: Williams M., Vogt W.P. The SAGE Handbook of Innovation in Social Research Methods. London: SAGE; 562-589.

Le Bas C., Mothe C., Nguyen-Thi T. U. 2015. The differentiated impacts of organizational innovation practices on technological innovation persistence. European Journal of Innovation Management 18 (1): 110127.

Lee S., Kim B. G., Kim H. 2012. An integrated view of knowledge management for performance. Journal of Knowledge Management 16 (2): 183-203.

Lin T.-C., Huang C.-C. 2008. Understanding knowledge management system usage antecedents: An integration of social cognitive theory and task technology fit. Information \& Management 45 (6): 410-417.

Little R. J., Rubin D. B. 2014. Statistical Analysis with Missing Data. John Wiley \& Sons: Hoboken, NJ.

Lotti Oliva F. 2014. Knowledge management barriers, practices and maturity model. Journal of Knowledge Management 18 (6): 1053-1074.

Manuti A., Pastore S., Scardigno A. F., Giancaspro M.L., Morciano D. 2015. Formal and informal learning in the workplace: A research review. International Journal of Training and Development 19 (1): 1-17.

Massingham P. 2014. An evaluation of knowledge management tools: Part 1 - managing knowledge resources. Journal of Knowledge Management 18 (6): 1075-1100.

Maynard M.T., Kennedy D. M., Sommer A. 2015. Team adaptation: A fifteen-year synthesis (1998-2013) and framework for how this literature needs to "adapt" going forward. European Journal of Work and Organizational Psychology 24 (5): 652-677.

Michailova S., Hutchings K. 2006. National cultural influences on knowledge sharing: A comparison of China and Russia. Journal of Management Studies 4 (3): 383-405.
Minbaeva D., Pedersen T., Björkman I., Fey C.F., Park H. J. 2003. MNC knowledge transfer, subsidiary absorptive capacity, and HRM. Journal of International Business Studies 34 (6): 586-599.

Moran J.W., Brightman B.K. 2001. Leading organizational change. Career Development International 6 (2): 111-118.

Nahapiet J., Ghoshal S. 1998. Social capital, intellectual capital and the organizational advantage. Academy of Management Review 23 (2): 242-266.

Nonaka I. Takeuchi H. 1995. The KnowledgeCreating Company: How Japanese Companies Create the Dynamics of Innovation. Oxford University Press: N.Y.

Park S., Kim E.-J. 2015. Revisiting knowledge sharing from the organizational change perspective. European Journal of Training and Development 39 (9): 769-797.

Penrose E. 1959. The Theory of the Growth of the Firm. Oxford University Press: Oxford.

Podsakoff P. M., MacKenzie S.B., Podsakoff N.P. 2012. Sources of method bias in social science research and recommendations on how to control it. Annual Review of Psychology 63: 539-569.

Puffer S., McCarthy D. 2011. Two decades of Russian business and management research: An institutional theory perspective. Academy of Management Perspectives 25 (2): 21-36.

Rafferty A.E., Jimmieson N.L., Armenakis A.A. 2013. Change readiness: A multilevel review. Journal of Management 39 (1): 110-135.

Razmerita L., Kirchner K., Nielsen P. 2016. What factors influence knowledge sharing in organizations? A social dilemma perspective of social media communication. Journal of Knowledge Management 20 (6): 1225- 1246.

Rigby D. 2001. Management tools and techniques: A survey. California Management Review 43 (2): 139-160.

Rigby D. 2015. Management Tools 2015: An Executive's Guide. [Electronic resource]. Available at: http://www.bain.com (accessed: January, 2018). 
Ringle C.M., Wende S., Becker J.-M. 2015. Smart PLS 3. SmartPLS GmbH: Bönningstedt. [Electronic resource]. Available at: http://www.smartpls.com (accessed: January, 2018).

Rubbo P., Picinin C.T., Pilatti L.A. 2018. Knowledge management practices and economic complexity in BRIC countries from 2001 to 2014. International Journal of Knowledge Management Studies 9 (1): 1-17.

Rusly F.H., Corner J.L., Sun P. 2012. Positioning change readiness in knowledge management research. Journal of Knowledge Management 16 (2): 329-355.

Rusly F.H., Sun P., Corner J.L. 2015. Change readiness: Creating understanding and capability for the knowledge acquisition process. Journal of Knowledge Management 19 (6): 1204-1223.

Schwab D.P. 2013. Research Methods for Organizational Studies. Psychology Press: N.Y.

Subramaniam M., Youndt M. A. 2005. The influence of intellectual capital on the types of innovative capabilities. Academy of Management Journal 48 (3): 450-463.

Teece D. J. 2009. Dynamic Capabilities and Strategic Management. Organizing for Innovation and Growth. Oxford University Press: N.Y.

Todnem By R. 2005. Organisational change management: A critical review. Journal of Change Management 5 (4): 369-380.

Wang W.-T., Hou Y.-P. 2015. Motivations of employees' knowledge sharing behaviors: A self-determination perspective. Information and Organization 25 (1): 1-26.

Weiner B. J., Amick H., Lee S. Y.D. 2008. Conceptualization and measurement of or- ganizational readiness for change: A review of the literature in health services research and other fields. Medical Care Research and Review 65 (4): 379-436.

Weiner B. J. 2009. A theory of organisational readiness for change. Implementation Science 67 (4): 1-9.

Wiig K.M. 1997. Integrating intellectual capital and knowledge management. Long Range Planning 30 (3): 399-405.

Wright K. 2005. Personal knowledge management: Supporting individual knowledge worker performance. Knowledge Management Research \& Practice 3 (3): 156165.

Youndt M.A., Subramaniam M., Snell S.A. 2004. Intellectual capital profiles: An examination of investments and returns. Journal of Management Studies 41 (2): 335361.

Zelenkov Y. 2016. Impact of knowledge management and change management on the effectiveness of the firm: Evidence from the Russian companies. KMO'16: Proceedings of the 11th International Knowledge Management in Organizations Conference on the Changing Face of Knowledge Management Impacting Society; July 25-28, Hagen, Germany. Article No.51. ACM: N.Y.

Zelenkov Y. 2018. The impact of knowledge management and change readiness on the effectiveness of Russian private and stateowned organizations. In: Uden L., Hadzima B., Ting I.H. (eds). Knowledge Management in Organizations. KMO 2018. Communications in Computer and Information Science, vol.877. Springer, Cham.

Initial Submission: June 13, 2018

Final Version Accepted: December 16, 2018

\section{Эффективность российских организаций: роль управления знанияли и готовности к изленениял}

\section{Ю.А. Зеленков}

Профессор, факультет бизнеса и менеджмента, НИУ «Высшая школа экономики», Москва, Россия E-mail: yuri.zelenkov@gmail.com 
Многие исследователи рассматривают знания как важнейший ресурс современной экономики, но эмпирические исследования показывают, что управление знаниями не входит в число наиболее популярных управленческих инструментов. Этот разрыв можно объяснить при помощи гипотезы о том, что управление знаниями оказывает значительное влияние на эффективность организации только при соответствующем развитии управления изменениями. При этом важнейшим элементом управления изменениями является готовность к изменениям. Она позволяет оценить возможность и целесообразность изменений, консолидировать и сфокусировать усилия, оценить адекватность имеющихся ресурсов. Сформулированная гипотеза протестирована на эмпирических данных о 103 российских организациях посредством моделирования структурными уравнениями с помощью частичных наименьших квадратов (PLS-SEM). Результаты показали, что эмпирическая выборка включает два статистически различных набора данных. Разделяющей переменной является тип собственника, поэтому были построены отдельные модели для частных и государственных организаций. Для частных организаций гипотеза о том, что управление знаниями и готовность к изменениям совместно влияют на эффективность, полностью подтвердилась. Для государственных организаций управление знаниями фактором эффективности не является. Полученные результаты позволяют сделать два вывода, важных для практической деятельности. Во-первых, менеджеры, считающие организационное знание важным ресурсом, должны фокусироваться на одновременном и скоординированном развитии практик управления знаниями и изменениями. Особое внимание необходимо уделять организационному контексту, поддерживающему индивидуальную готовность к изменениям. Во-вторых, государственные организации в России менее эффективны, чем частные, поскольку управление знаниями не является для них фактором эффективности; это выступает следствием подавления инициативы на индивидуальном уровне.

Ключевые слова: управление знаниями, управление изменениями, готовность к изменениям, эффективность организации, частные организации, государственные организации.

JEL: D20, D83, M14, 032.

For citation: Zelenkov Y.A. 2018. The effectiveness of Russian organizations: The role of knowledge management and change readiness. Russian Management Journal 16 (4): 513-536. https:// doi.org/10.21638/spbu18.2018.403

https://doi.org/10.21638/spbu18.2018.403

Статья поступила в редакцию

13 июня 2018 г.

Принята к публикации

16 декабря 2018 г.

RMJ 16 (4): 513-536 (2018) 